\title{
ERRATUM
}

\section{Erratum to: Safety and Tolerability of Fingolimod in Latin American Patients with Relapsing-Remitting Multiple Sclerosis: The Open-Label FIRST LATAM Study}

Laura Ordoñez-Boschetti $\cdot$ Roberto Rey $\cdot$ Ana Cruz $\cdot$

Arijit Sinha $\cdot$ Tracy Reynolds $\cdot$ Nadina Frider $\cdot$ Regina Alvarenga

To view enhanced content go to www.advancesintherapy.com

Published online: July 28, 2015

(C) The Author(s) 2015. This article is published with open access at Springerlink.com

Erratum to: Adv Ther

DOI 10.1007/s12325-015-0224-2

The authors of the above mentioned paper would like to make the following correction to the author list.

The online version of the original article can be found under doi:10.1007/s12325-015-0224-2.

L. Ordoñez-Boschetti

Consultorio de Medicina Especializada del Sector

Privado, Mexico City, Mexico

R. Rey

Instituto Argentino de Investigación Neurológica,

Buenos Aires, Argentina

A. Cruz

Centro de Investigaciones Médicas Hospital

Nacional Alberto Sabogal Sologuren, Callao-Lima,

Peru

A. Sinha

Novartis Healthcare Pvt. Ltd., Hyderabad, India

T. Reynolds

Novartis Pharma AG, Basel, Switzerland

N. Frider

Novartis LAtinAmerica and Canada Region,

Buenos Aires, Argentina

R. Alvarenga ( $\square)$

MS Hospital Da Lagoa, Rio de Janeiro, Brazil

e-mail: regina_alvarenga@hotmail.com
Laura Ordoñez-Boschetti · Roberto Rey · Ana Cruz · Arijit Sinha · Tracy Reynolds · Nadina Frider · Regina Alvarenga

The original article has been updated accordingly.

Open Access. This article is distributed under the terms of the Creative Commons Attribution Noncommercial License which permits any noncommercial use, distribution, and reproduction in any medium, provided the original author(s) and the source are credited. 